\title{
KIDNEY DONATION AND THE CONSENT OF THE POOR
}

\author{
Philip J. Cook* and Kimberly D. Krawiec ${ }^{* *}$
}

\section{INTRODUCTION}

In Consentability, Nancy Kim tackles the difficult question of why we permit people to consent to some activities but not others, and where the line should be drawn. ${ }^{1}$ The guiding principle, rooted in John Stuart Mill's Harm Principle, favors freedom from government intervention-adults should be allowed to consent to risky activities or transactions, so long as there are no negative impacts on others. ${ }^{2}$ In particular, the law should not intrude on personal choices that entail financial risks or risk of injury. But this anti-paternalism stricture is violated in practice, often for understandable reasons. ${ }^{3}$ If a judge orders that a suicidal college student be deprived of his gun, most people would endorse this imposition on his freedom. ${ }^{4}$ But in other cases there is no

* Terry Sanford Professor Emeritus of Public Policy, Sanford School of Public Policy, Professor Emeritus of Economics and Sociology, Duke University.

** Kathrine Robinson Everett Professor of Law, Duke University School of Law; Senior Fellow, Kenan Institute for Ethics, Duke University.

1. NANCY S. KIM, CONSENTABLITY: CONSENT AND ITS LIMITS (2019).

2. See JOHN STUART MILL, ON LIBERTY (1859) ("The only purpose for which power can be rightfully exercised over any member of a civilized community, against his will, is to prevent harm to others. His own good, either physical or moral, is not a sufficient warrant.").

3. Philosophers divide sharply on whether governmental paternalism can be justified, with many believing that such interventions are defensible if the restraints on individual autonomy are sufficiently small and the benefits to the individual are sufficiently large. See Tom Beauchamp, The Principle of Beneficence in Applied Ethics, STANFORD ENCYCLOPEDIA OF PHILOSOPHY (2019), https://plato.stanford.edu/entries/ principle-beneficence/.

4. Extreme risk protection orders, familiarly known as "red flag laws," have been enacted in 17 states as of September 2019. While the details differ from state to state, they generally provide for the possibility of family members and law enforcement officers to petition a court for an order to temporarily remove guns from the possession of a person who appears to be an immediate threat to him- or herself, or to others. A national survey in July, 2019 found that $77 \%$ of the adult public supported adoption of such a law. See Gun Survey, APM RESEARCH LABS, https://www.apmresearchlab.org/ gunsurvey (last visited Oct. 20, 2019). 
consensus, as, for example, with the evolving laws governing marijuana and gambling. Professor Kim's new book provides a thorough account of the scholarly debate about the relevant principles and the application of these principles, with a variety of interesting examples.

In particular, Kim focuses on what she considers the "hard cases" for consentability. She identifies three categories of "hard cases": self-directed activities, novel high-risk activities, and "bodily integrity exchanges." activities, are those "undertaken by an individual upon his own initiative and control." ${ }^{\text {Th }}$ This category includes "self-harming" activities such as suicide; "self-improvement" activities that pose some health risk such as cosmetic surgery, tattoos, and voluntary amputation; and activities such as smoking tobacco, drinking alcohol, and using recreational drugs that are intended neither for self-harm nor self-improvement, but that carry risk for the individual participant. ${ }^{7}$ The second category, novel high-risk activities, includes new and unusual undertakings like travel to Mars and participating in some experimental studies. ${ }^{8}$

It is the third category of "bodily integrity exchanges" that is the focus of our comments here. Kim defines this category to include commercial surrogacy, as well as payment for donating a kidney or ova-topics about which we have previously written in some detail. ${ }^{9}$ She reviews most of the reputable arguments, and despite serious concerns, reaches a positive conclusion-that these exchanges should be viewed as "consentable" with certain provisos. ${ }^{10}$ We agree with that conclusion but disagree about the specific provisos. Her core concern is that some people, due to their "desperate" poverty, will be tempted by an offer of a substantial cash payment when it is not in their true self-interest to do so. ${ }^{11}$ In our view, her proposal to require special screening for potential

5. NANCY S. KIM, CONSENTABILITY: CONSENT AND ITS LIMITS 18 (2019).

6. Id. at 19 .

7. Id.

8. Id. at 44 .

9. See, e.g., Philip J. Cook \& Kimberly D. Krawiec, A primer on kidney transplantation: anatomy of the shortage, 77 LAW \& CONTEMP. PROBS. 1 (2014); Philip J. Cook \& Kimberly D. Krawiec, If We Allow Football Players and Boxers to Be Paid for Entertaining the Public, Why Don't We Allow Kidney Donors to Be Paid for Saving Lives, 81 LAW \& CONTEMP. PROBS. 9 (2018); Kimberly D Krawiec,, Lessons from Law About Incomplete Commodification in the Egg Market, 33.2 J. APPL. PHILOS., 160-177 (2016).

10. NANCY S. Kim, Consentability: ConSENT AND ITS Limits 32-44 (2019).

11. Id. at 198-99. 
donors who are poor is problematic. An alternative, which we think would be salutary generally (not just for the poor) is to structure the payout so that potential donors are not confronted by the temptation of an immediate windfall gain in exchange for undergoing the risky procedure of donation. Behavioral science offers guidance on how to structure the payment to encourage better decisions.

For the particular case of payment for kidney donation by a living donor, we offer two additional suggestions, both intended to draw on a different intuition by reframing the argument. Our first suggestion is to consider kidney donation in the context of a wide array of risky but productive tasks. Our goal is to encourage a conversation about kidney donation that is not tainted by specific concerns associated with sex work and surrogacy. Lumberjacks, deep-sea fishermen, and some athletes place their bodies at considerable risk in exchange for a premium wage, doing work that (unlike sex work) is generally recognized as valuable and unproblematic aside from the physical risk. We believe that viewing the issue of consentability for paid kidney donation as analogous to the issue of consentability for working on a fishing boat clarifies the key issue relevant to consent. When Kim instead associates it with sex work and surrogacy, the result is to raise specific ethical concerns and distracting visceral responses.

A second and more radical reframing is to suggest a different starting point for the evaluation of paid kidney donation. There are some commentators who suggest that kidney donation is a duty for those who are healthy - much like serving in the military during time of war. ${ }^{12}$ After all, thousands of people are dying from renal failure every year for want of kidney donors. ${ }^{13}$ The issue of consent is transformed in this framing; the relevant question is not who should be allowed to consent to donate a kidney, but rather who

12. See Cécile Fabre, Justice and the Compulsory Taking of Live Body Parts, 15 UTILITAS 127, 127-150 (2003) (arguing that the sick sometimes have a moral claim on the body parts of the living); Julian Savulescu, Peter Singer \& William Isdale, We Have a Moral Obligation to Donate Organs, Sydney Morning Herald (Aug. 24, 2015), https://www.smh.com.au/opinion/australias-poor-organ-donation-rate-costing-lives-20 150824-gj60ov.html (arguing that there is a moral duty to donate one's organs after death); see also CÉCILE FABRE, WhOSE BODY IS IT ANYWAY?: JUSTICE AND THE INTEGRITY OF THE PERSON (2006) (arguing that the sick may have a moral claim on the body parts of the living).

13. Transplant Trends, UNITED NETWORK FOR ORGAN SHARING, https://unos.org/data/transplant-trends/ (last visited Oct. 26, 2019) (In 2017, more than 6,500 people died while awaiting a transplant or within thirty days after being removed from the transplant waitlist because they were too ill to be transplanted). 
should be allowed to opt out of the duty to donate a kidney. While we do not endorse this framing, we believe that it is useful as a reminder that the stakes in recruiting enough donors are very high.

\section{BODILY INTEGRITY EXCHANGES}

Bodily integrity exchanges are "highly controversial because they involve monetary payment for the use or possession of a part of the human body."14 Included in this category are "sex work/prostitution, the selling of kidneys, and reproductive services." ${ }^{15} \mathrm{Kim}$ correctly notes that it is not the riskiness of these activities that render them controversial. Though each involves some level of risk, that risk is generally viewed as acceptable in the absence of payment. ${ }^{16}$ Kidney donors are heroes, and sex in the absence of payment is considered a normal part of romantic relations.

Professor Kim details a number of arguments typically raised against these "noxious" or "repugnant" transactions. ${ }^{17}$ One of the most common objections is that such transactions commodify and thus degrade the human body and social relations more generally. ${ }^{18} \mathrm{Kim}$ appears skeptical of this argument, correctly pointing out the myriad situations in which we accept the bodily commodification and even outright degradation of particular groups, especially women. Says Kim:

Many societies thrive upon the commodification of the (female) body, and permit payment to alter the natural state of that body through cosmetic procedures, including risky and invasive surgeries. Why should a woman be permitted to pay someone to perform medically unnecessary surgical procedures and prohibit that same women [sic] from getting paid to undergo arguably less risky and invasive acts such as surrogacy or egg extractions? ${ }^{19}$

14. NANCY S. KIM, CONSENTABILITY: CONSENT AND ITS LIMITS 32 (2019).

15. Id.

16. $I d$.

17. $I d$.

18. Id. at 33; MichaEL J. SANDEL, WHAT MONEY CAN'T Buy: The MORAL Limits OF MARKETS (2012) (arguing that the social meaning of certain items and activities are corrupted by the marketplace).

19. NANCY S. KIM, CONSENTABILITY: CONSENT AND ITS LIMITS 34 (2019). 
Kim appears to take more seriously a second objection, which is that bodily integrity transactions "exploit the poor and promote inequality." ${ }^{20}$ Kim hypothesizes that because it is "highly unlikely that wealthy people will be selling their kidneys or other organs," bodily integrity transactions "would likely exacerbate the unfairness and stratification in a society that values both justice and equality." 21

After weighing the various arguments, Kim ultimately rejects a ban on legalized markets in bodily integrity transactions, proposing instead a "presumption of defective consent" in bodily integrity exchanges involving the "desperately poor."22 Although we agree with many of Kim's recommendations, particularly those designed to improve the consent process and overcome shortsighted or uninformed decision-making, we also question some of her assumptions regarding bodily integrity exchanges and decision-making by the poor more generally.

Kim would permit bodily integrity markets, subject to some limitations. Although no one is prohibited from participating in bodily integrity exchanges, Kim is specifically concerned about the "desperately poor" and their consent to such exchanges is presumed defective. Those seeking to transact with the desperately poor in a bodily integrity exchange would have to prove that the interaction was originated by the desperately poor person and that the terms of the exchange are fair and not exploitative. ${ }^{23}$ We agree with Kim that legal rules should seek to ensure that risky transactions are fair and undertaken on an informed basis. But we resist the idea of differential review for those who are "desperately" poor by some, inevitably arbitrary, standard. Instead, our emphasis has been on how payments could be structured to minimize the possibility of impulsive sales. ${ }^{24}$ As with removing the gun from the hands of the suicidal college student, we believe that decisions of this sort should require a chance for reflection.

Kim acknowledges the definitional difficulties in determining who is desperately poor but proposes, as one possibility, an income

20. NANCY S. KIM, CONSENTABILITY: CONSENT AND ITS LIMITS 35 (2019).

21. Id. at 37 .

22. Id. at 200 .

23. Id.

24. Philip J. Cook \& Kimberly D. Krawiec, If We Allow Football Players and Boxers to be Paid for Entertaining the Public, Why Don't We Allow Kidney Donors to be Paid for Saving Lives?, 81 L. \& CONTEMP. PROBS. 9, 29-32 (2018). 
test that would categorize those at a certain percentage below the poverty line as desperately poor. ${ }^{25}$ To be sure, in some markets in some places donors living below the poverty line are active participants in some types of bodily integrity exchanges. For example, in Iran, the only country in the world to legalize organ markets, one study found that $62 \%$ of living unrelated donors had incomes below the poverty line. ${ }^{26}$ But because of consumer interest (some would say obsession) with egg donor traits such as education, IQ, and athletic ability, egg donors in the United States have significantly higher educational levels (a common though imperfect proxy for socio-economic status) than the general population. ${ }^{27}$ This feature of the market, of course, has not eliminated claims by market critics that egg donors are financially coerced and exploited. ${ }^{28}$

Kim's proposed income definition would fail to address other forms of financial distress that might influence or impair decisionmaking, including indebtedness (many egg donors are students) or financial setbacks. In other words, the promised compensation from a bodily integrity exchange may be a significant lure for a wide array of people of limited means, which is to say most adults in the age range where they would qualify as medically attractive donors. The chance to make, say, $\$ 50,000$ by donating a kidney, should that be legalized, would have broad appeal. And it should be noted that this payment may help donors accomplish their purpose by providing them with the wherewithal to eliminate financial barriers to moving on with their lives, potentially enhancing economic mobility. The point is that there should be no presumption that it is a mistake for someone of limited means to donate, nor that it reinforces societal stratification. Even if Kim is correct that the poor are disproportionately likely to be the suppliers of kidneys in a paid system (as is true in a variety of occupations, risky or otherwise), the poor would also

25. NANCY S. KIM, CONSENTABILITY: CONSENT AND ITS LIMITS 198 (2019).

26. T. Malakoutian et al., Socioeconomic Status of Iranian Living Unrelated Kidney Donors: A Multicenter Study, 39 TRANSPLANTATION PROCEEDINGS 824, 824 (2007).

27. Cynthia R. Daniels \& Erin Heidt-Forsythe, Gendered Eugenics and the Problematic of Free Market Reproductive Technologies: Sperm and Egg Donation in the United States, 37 SIGNS: J. WOMEN CULTURE \& SOC'Y 719, 731-32 (2012) (finding that egg donors were more than twice as likely as the general population to have earned a college degree and that $100 \%$ of egg donors in a more than 350 person sample had finished high school).

28. See Kimberly D. Krawiec, Sunny Samaritans and Egomaniacs: Price-Fixing in the Gamete Parket, 72 L. \& CONTEMP. PROBS. 59 (2009) (summarizing these arguments). 
disproportionately benefit from a public system that compensates donors and distributes kidneys according to medical need, because the poor are also more likely to suffer from end stage renal disease. ${ }^{29}$

In our view, the problem is not that people of limited means would greatly increase their rate of kidney donation in response to an offer of substantial payment. That is an inevitable part of the solution to the kidney shortage. The problem is that if the offer were made in the form of a lump sum to be paid immediately when someone volunteered, then it would be too much of a temptation for some potential donors, poor and middle class alike, who would go on to subsequently regret their decision. Consent for such a momentous decision should follow careful reflection-as in Psychologist (and Nobel Laureate) Daniel Kahneman's famous term "system 2 thinking," which in contrast to the quick, impulsive judgments of system 1 thinking, is instead slow, analytical, and effortful. ${ }^{30}$ Of particular concern is taking the time to reduce "optimism bias," the general tendency in evaluating a course of action (such as renovating a kitchen) to overestimate benefits and underestimate costs. ${ }^{31}$ To reduce the allure of jackpot earnings and encourage due reflection, the contract for a volunteer kidney donor could delay any payment until after a period of medical and mental-health screening and consultation, and whatever delays before the kidney is needed. Another possibility would be to make the payment over a period of years, in the form of an annuity. The goal of structured payments is to complement the screening and counseling process to reduce the chance that donors would act impulsively and have unrealistic expectations.

\section{FINDING THE RIGHT FRAME FOR KIDNEY DONATION}

Professor Kim assigns kidney and egg donation to the same category as prostitution and surrogacy, under the umbrella of "bodily integrity exchanges." While that is reasonable up to a point, we are concerned that placing organ donation in such company will prejudice judgment about how it should be regulated.

29. Philip J. Held et al., Would Government Compensation of Living Kidney Donors Exploit the Poor? An Empirical Analysis, PLOS ONE (2018), available at https:// doi.org/10.1371/journal.pone.0205655.

30. See Daniel Kahneman, Thinking, Fast and Slow, Part I (Farrar, Strauss, and Gireau, 2011) (explaining the two systems in which the brain forms thoughts).

31. See DANIEL KAHNEMAn, ThinkING, FAST AND SlOW, Part II (Farrar, Strauss, and Gireau, 2011) (explaining the phenomenon of human thinking using heuristics). 
Sex work in particular raises ethical concerns that are not a part of organ donation. While kidney donors are heroic, that term is rarely applied to sex workers, even by those (including us) who do not object to their profession.

Currently, and unfortunately, the "heroic" label is largely reserved for unpaid kidney donors. Anthropologists have found that paid donors, in contrast, are generally considered victims (as they often are in the black market) or are socially stigmatized..$^{32}$ But we think it likely that under an appropriately regulated system paid kidney donors will come to be regarded much as paid military members are today-as heroes who are compensated for their time, effort, and sacrifice. The social framing of the act may be important in this effort, as it is in legitimizing the ova market, where gift framing is prominent. ${ }^{33}$ Some research, for example, suggests that "heroism awards" are more politically palatable than framing donor compensation as a financial inducement. ${ }^{34}$

An alternative and less loaded category in which to consider organ donation is that of risky occupations. Workers such as lumberjacks, crew on deep-sea fishing boats, and structural steel workers face a very high risk of injury. ${ }^{35}$ There is no question that they are doing useful work that contributes to our standard of living, and no concerted objection to the practice of allowing people to volunteer for such jobs-which typically pay a premium compared to what they could make otherwise. Many of the workers in such occupations come from poor households and communities and lack much education. The analogy to compensated kidney donation (another productive activity, should it be legalized) seems clear, and an analysis of consentability should reach the same conclusion.

32. See, e.g., Farhat Moazam, Riffat Moazam Zaman, \& Aamir M. Jafarey, Conversations with Kidney Vendors in Pakistan: An Ethnographic Study, 39 HastingS CTR. REP. 29 (2009); Javaad Zargooshi, Quality of Life of Iranian Kidney "Donors", 166.5 J. UROLOGY 1790 (2001).

33. Rene Almeling, Sex Cells: The Medical Market for EgGS AND SPERM (2011); Krawiec, supra note 28.

34. See Muriel Niederle \& Alvin E. Roth, Philanthropically Funded Heroism Awards for Kidney Donors, 77 L. \& CONTEMP. Probs. 131 (2014).

35. Michael B. Sauter \& Charles Stockdale, The Most Dangerous Jobs in the US Include Electricians, Firefighters and Police Officers, USA TODAY (Jan. 8, 2019), https://www.usatoday.com/story/money/2019/01/08/most-dangerous-jobs-us-where-fat al-injuries-happen-most-often/38832907/ (rankings based on 2018 data from the Bureau of Labor Statistics' annual National Census of Fatal Occupational Injuries Report). 
A more radical reframing of kidney donation is to change the focus from the potential donors to the renal-failure patients for whom a new kidney would extend their life by years and reduce the disability associated with renal dialysis. Federal law bans offering payment to donors, and while 6,000 living donors are found each year (almost always to donate to a family member or friend), the result of banning compensation is a massive shortage amounting to 15,000-20,000 kidneys per year. ${ }^{36}$ Any adult in good health under age sixty-five with two kidneys is in a position to donate, since the second kidney is entirely redundant in bodily functioning. The operation is by no means trivial and creates some medical risk both during and after, not to mention substantial discomfort during the healing process. But the great majority of donors are fully recovered within a few months. In previous work, we compared kidney donation with playing professional football; ${ }^{37}$ the evidence is clear that football carries far more risk to long-term health and functioning. Given that kidney donation is an option for most adults in a medical sense, there is a case to be made that it is also a duty. ${ }^{38}$ If we have a reasonable chance to save a fellow human, is there then an obligation to do so? Such an obligation is not built into the law-there is no general "duty to rescue" in United States law or that of most other countries-but has been seen by some commentators as an ethical duty. ${ }^{39}$ We do not endorse that position but find it interesting as an alternative to the focus generally found in the literature (and Professor Kim's book) on the welfare of the potential donor. The welfare of the renal patient could be made integral to the analysis. The concern that paying donors would somehow devalue their contribution by making the donated kidney into a "commodity" would be trumped by a realization that the ban on payment has the effect of causing

36. See Philip J. Cook \& Kimberly D. Krawiec, If We Allow Football Players and Boxers to be Paid for Entertaining the Public, Why Don't We Allow Kidney Donors to be Paid for Saving Lives?, 81 L. \& CONTEMP. PROBS. 9 (2018).

37. See id.

38. See Cécile Fabre, Justice and the Compulsory Taking of Live Body Parts, 15 UTLITAS 127, 127-150 (2003) (arguing that the sick sometimes have a moral claim on the body parts of the living); Julian Savulescu, Peter Singer \& William Isdale, We Have a Moral Obligation to Donate Organs, SYDNEY MoRNing Herald (Aug. 24, 2015), https://www.smh.com.au/opinion/australias-poor-organ-donation-rate-costing-lives20150824-gj60ov.html (arguing that there is a moral duty to donate one's organs after death); see also CÉCILE FABRE, WHOSE BODY Is IT ANYWAY?: JUSTICE AND THE INTEGRITY OF THE PERSON (2006) (arguing that the sick may have a moral claim on the body parts of the living).

39. See David A. Hyman, Rescue Without Law: An Empirical Perspective on the Duty to Rescue, 84 TEX. L. REV. 653, 653 (2006). 
thousands of deaths and much unnecessary suffering. The concern that low-income donors would in some sense find the offer of payment too attractive could be balanced against a realization that their action, even if ill-considered, would likely save a life and deserves compensation.

\section{CONCLUSION}

In Consentability, Nancy Kim tackles an important and current topic-in an age of increasing options about how to live, die, and procreate, what limits, if any, should the law place on those choices? Consentability is a valuable resource for scholars and policymakers alike, summarizing the arguments for and against government intrusion on the choices of consenting adults with encyclopedic thoroughness. After weighing the arguments, Kim proposes that "bodily integrity exchanges" be permitted, subject to limitations. Although we agree with the general conclusion that bodily integrity exchanges should be permitted, we disagree with the specific limitations that treat the decisions of the poor as suspect, proposing instead methods of structuring payments and the consent process that would enhance the decision-making quality and reduce the possibility of impulsive decisions for all donors-not just those meeting an arbitrary definition of poverty. In any event, when it comes to a life-saving transaction like kidney donation, it is ethically important to consider the welfare of the recipient as well as the donor. 